\title{
Controlling hazardous chemicals in microreactors: Synthesis with iodine azide
}

\author{
Johan C. Brandt and Thomas Wirth*
}

\author{
Full Research Paper \\ Address: \\ Cardiff University, School of Chemistry, Park Place, Cardiff CF10 \\ 3AT, UK. \\ Email: \\ Thomas Wirth* - wirth@cf.ac.uk \\ * Corresponding author \\ Keywords: \\ azide; flow chemistry; hazardous reagents; microreactor; \\ rearrangement
}

\author{
Beilstein Journal of Organic Chemistry 2009, 5, No. 30 \\ doi:10.3762/bjoc.5.30 \\ Received: 23 March 2009 \\ Accepted: 04 June 2009 \\ Published: 12 June 2009 \\ Guest Editor: A. Kirschning \\ (c) 2009 Brandt and Wirth; licensee Beilstein-Institut. \\ License and terms: see end of document.
}

\begin{abstract}
Aromatic aldehydes have been converted into the corresponding carbamoyl azides using iodine azide. These reactions have been performed safely under continuous flow reaction conditions in microreactors.
\end{abstract}

\section{Introduction}

Microstructured devices have already found their way into organic synthesis, because they offer various advantages over traditional large-scale chemistry performed in flasks or vessels $[1,2]$. The high surface-to-volume ratio as their main characteristic can result in rapid mixing of compounds, uniform reaction conditions due to precise temperature control as well as rate enhancements because of short diffusion distances. In addition, the synthesis and use of potentially hazardous compounds is another advantage of microreactors as only very small amounts of compounds/reagents are handled. Large inventories of dangerous reagents and intermediates are not necessary.

Azides are among the most versatile reagents in modern organic chemistry however they are not often used to their full potential due to safety concerns. Especially azides with low molecular weights are difficult to handle because of their high disposition to detonate [3-5]. However, azides are extremely useful moieties in organic synthesis as they can be transformed easily into a large variety of other functional groups [5].

Iodine azide is a very hazardous but valuable reagent that is easier and much more safely handled under microreactor conditions. Iodine azide is a solid compound, highly explosive and toxic. It is known to add stereospecifically to carbon-carbon double bonds with high regioselectivity following an ionic mechanism. This azido-iodination reaction is by far the most common synthetic application of iodine azide [6-14]. Due to the weakness of the iodine-nitrogen bond iodine azide also reacts in a radical manner upon heating, where this weak bond can be homolytically cleaved and introduce azide moieties efficiently into molecules with weak carbon-hydrogen bonds such as benzyl ethers $[15,16]$ or aldehydes [17,18]. Recently some other research groups have investigated the use of azides in chemistries performed in microreactors [19-22]. 


\section{Results and Discussion}

The radical addition of azide to aldehydes $\mathbf{1}$ initially forms acyl azides $\mathbf{2}$ which directly rearrange in a Curtius rearrangement to the corresponding isocyanates $\mathbf{3}$. Isocyanates are very reactive themselves and offer a wide range of possible conversions. An excess of azide leads to the formation of stable carbamoyl azides 4 as shown in Scheme 1 .

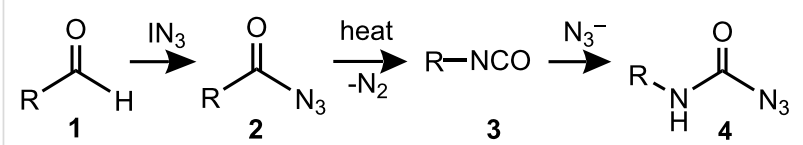

Scheme 1: Azide addition to aldehydes and formation of carbamoyl azides.

As sodium azide is poorly soluble in organic solvents, we decided to use tetrabutylammonium azide for the in situ generation of iodine azide. The reaction with iodine monochloride is rapid and after several minutes (depending on the flow rate) the aldehyde $\mathbf{1}$ was added to the reagent in the microreactor as shown in Figure 1.

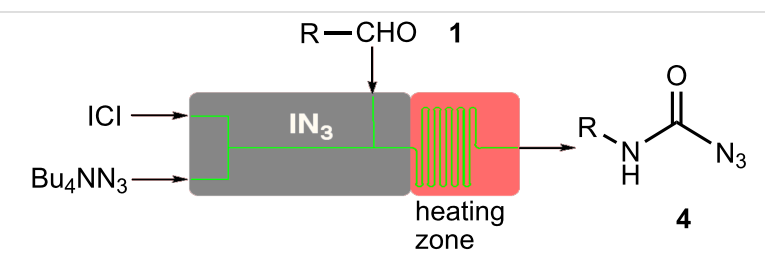

Figure 1: Microreactor setup for the in situ generation and use of iodine azide $\left(\mathrm{IN}_{3}\right)$.

All reagents and the aldehyde $\mathbf{1}$ were used as solutions in acetonitrile. After mixing the aldehyde with the iodine azide reagent the solution is passed through a capillary (volume: $196 \mu \mathrm{L}$ ) in a heating zone to allow the Curtius rearrangement to occur. Flow rates of $20 \mu \mathrm{L} / \mathrm{min}$ or higher led to very low or no conversion. At slower flow rates the yields were enhanced but seemed to stop growing at one point. Optimal yields were constant within a range of 15 to $1.5 \mu \mathrm{l} / \mathrm{min}$ corresponding to residence times in the heating zone of 13-130 minutes. For optimization experiments benzaldehyde 1a was used. Slower flow rates are technically possible but not very attractive from a synthetic point of view. The reaction would work best at $80{ }^{\circ} \mathrm{C}$, just below the boiling point of acetonitrile. Lower temperatures gave lower conversions. A reaction at $65{ }^{\circ} \mathrm{C}$ produced the product $4 \mathrm{a}$ in only $25 \%$ yield, whereas a reaction at room temperature did not yield any product. An exchange of the solvent for propionitrile allowed a temperature increase to $110{ }^{\circ} \mathrm{C}$, but conversions were found to be similar to reactions using acetonitrile. In the original publication the solvent had already been optimized and acetonitrile seemed to be the best solvent for this reaction [17].
When using non-distilled $p$-bromobenzaldehyde $\mathbf{1 c}$ the reaction stopped with the formation of the acyl azide $\mathbf{5}$ contrary to the corresponding chloride derivative (Table 1). However when we modified the protocol to only using freshly distilled aldehydes, we also observed reaction and rearrangement of $1 \mathbf{c}$ via 5 to $4 \mathbf{c}$ and increased yields for the other reactions.

Table 1: Products and yields in the addition of iodine azide to aldehydes performed in a tubing microreactor at a flow rate of $7.5 \mu \mathrm{L} / \mathrm{min}$ (26 min residence time) at $80^{\circ} \mathrm{C}$.

\begin{tabular}{|c|c|c|c|}
\hline Entry & Aldehyde 1 & Product & $\begin{array}{l}\text { Yield } \\
{[\%]}\end{array}$ \\
\hline
\end{tabular}

1<smiles>O=Cc1ccccc1</smiles>

1 a<smiles>O=Cc1ccc(Cl)cc1</smiles>

$1 \mathrm{~b}$<smiles>O=Cc1ccc(Br)cc1</smiles>

$1 c$ not distilled<smiles>O=Cc1ccc(Br)cc1</smiles>

1c distilled<smiles>N#CC(=O)Nc1ccccc1</smiles>

$4 a$<smiles>NC(=O)Nc1ccc(Cl)cc1</smiles>

$4 b$<smiles>NC(=O)c1ccc(Br)cc1</smiles>

5<smiles>NC(=O)Nc1ccc(Br)cc1</smiles>

4c
5<smiles>COc1ccc(C=O)c(OC)c1</smiles>

$1 d$<smiles>COc1ccc(NC(N)=O)c(OC)c1</smiles>

4d

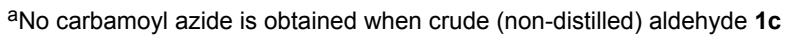
is used. 
We could show that the quality of the tetrabutylammonium azide is important for the success of the reaction. Its preparation from tetrabutylammonium hydroxide and sodium azide in water and dichloromethane did not lead to dry, crystalline material [23]. Unfortunately also the procedure using tetrabutylammonium chloride and sodium azide produced a product highly contaminated with DMF, which was not removable without decomposition of the product [24,25]. Highest yields were obtained with commercially available tetrabutylammonium azide (Aldrich), although great care has to be taken as this compound is very hygroscopic. Calculations indicate that the synthesis of iodine azide from trimethylsilyl azide and iodine monochloride is slightly endothermic $(\Delta \mathrm{H} \approx+15 \mathrm{~kJ} / \mathrm{mol})$ [26-29]. Geometry optimisations and frequency analyses on $\mathrm{Me}_{3} \mathrm{SiN}_{3}, \mathrm{ICl}, \mathrm{IN}_{3}$ and $\mathrm{Me}_{3} \mathrm{SiCl}$ were performed using Gaussian 98 at the B3LYP/6-311+G(d,p) level using the LANL2DZ basis set for iodine augmented with one $\mathrm{p}$ function and one $\mathrm{d}$ function. NMR experiments showed a ratio of about 1:3 of trimethylsilyl azide and trimethylsilyl chloride upon reaction with iodine monochloride. This mixture was not efficient in the reaction with aldehydes, only an unidentifiable mixture of products was obtained.

The reactivity of carbamoyl azides is analogous to isocyanates, compound 4a reacted with $n$-butyllithium to give amide 6 in quantitative yields as shown in Scheme 2.

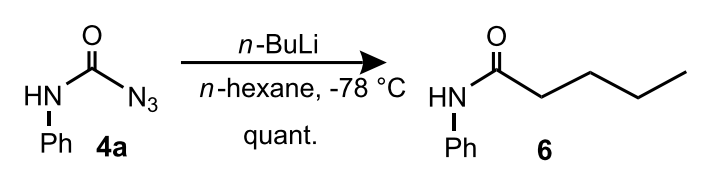

Scheme 2: Reaction of carbamoyl azide 4a with $n$-butyllithium.

Another way to form a stable iodine-azide bonds are hypervalent iodine compounds [30,31]. This source of reagent has indeed been used for radical azidonations in flask reactions [18] and resulted in an interesting approach using solid support [32], but these compounds are usually unsuitable for applications in microreactors because of their poor solubility or they would require a different microreactor set-up that would allow solid supported reagents [33].

For better comparison with literature procedures the reaction was then also investigated as a batch process. The reaction with commercial tetrabutylammonium azide and non-distilled aldehyde precursors would stop after the formation of the acyl azide with $p$-chlorobenzaldehyde and with $p$-bromobenzaldehyde. Rearrangement took place when sodium azide was used, but lower yields ( $34 \%$ yield of $\mathbf{4 b}$ ) were observed than those given in literature (53-97\%) [17]. Maybe the sodium ion acts like a
Lewis acid and accelerates the rearrangement. It is known that Lewis acid catalysts such as zinc triflate can accelerate Curtius rearrangements and the sodium cation might serve a similar role [34]. We obtained $67 \%$ yield of $\mathbf{4 b}$ when zinc triflate was used as catalyst in a flask reaction. Even the reaction of non-distilled $p$-bromobenzaldehyde 1c under these acidic conditions showed traces of the corresponding carbamoyl azide according to ${ }^{1} \mathrm{H}$ NMR. But electron rich substrates such as 2,4-dimethoxybenzaldehyde 1d showed decomposition and unidentifyable product mixtures with this catalyst. Generally, the batch reactions all proceeded less cleanly compared to the microreactor processes.

\section{Conclusion}

After initially promising results we were challenged with a complex optimization task, that included many more parameters than usual in organic synthesis, due to the technical implications of our approach. There are phenomena in this reaction that prevent complete conversion to complete by a long way, probably azide-consuming side reactions or lack of activity of the substrate, lack of acid catalysis, or a combination of these reasons. Additionally, the substitution pattern of the substrates led to an unexpected outcome of the reaction.

\section{Experimental}

\section{Synthesis of tetrabutylammonium azide:}

Procedure I [23]: Sodium azide (200 mmol, 13 g) was dissolved in water $(30 \mathrm{~mL})$. Then tetrabutylammonium hydroxide (100 mmol, $26 \mathrm{~g}$ ) was added and the mixture was stirred at room temperature for $90 \mathrm{~min}$. Dichloromethane (50 $\mathrm{mL}$ ) was added and stirring was continued for $10 \mathrm{~min}$. The organic layer was separated and dried over magnesium sulfate. Finally the solvent was removed under reduced pressure and the product was dried for $24 \mathrm{~h}$ under vacuum.

Procedure II [24,25]: Sodium azide (79 mmol, $5.13 \mathrm{~g}$ ) and tetrabutylammonium chloride ( $85 \mathrm{mmol}, 22 \mathrm{~g}$ ) were mixed in DMF $(35 \mathrm{~mL})$ and stirred overnight under argon at $50{ }^{\circ} \mathrm{C}$. Dry THF (70 mL) was added and stirring continued for $15 \mathrm{~min}$. The reaction mixture was filtered and the solvent in the filtrate was removed under reduced pressure. The product was heated under vacuum for $2 \mathrm{~h}$ to remove some DMF.

Yields for these reactions cannot be given as the solvents could not be removed completely from the product. IR (Nujol, $\mathrm{cm}^{-1}$ ): $v=3418,2145$ (azide), 1643.

\section{General procedure for the synthesis of carbamoyl azides 4:}

A twin syringe pump (KDS-200-CE) was charged with two 5 $\mathrm{ml}$ Hamilton syringes, one containing tetrabutylammonium azide ( $3 \mathrm{mmol}, 853 \mathrm{mg}$ ) in dry acetonitrile $(3.5 \mathrm{~mL})$ and the 
other iodine monochloride $(2 \mathrm{mmol}, 102 \mu \mathrm{L})$ in dry acetonitrile $(4.8 \mathrm{~mL})$. The outlets were connected by standard HPLC tubing to a $\mathrm{T}$-junction, after $30 \mathrm{~cm}$ tubing a second $\mathrm{T}$-junction was connected to the third syringe containing the substrate aldehyde $(1 \mathrm{mmol})$ in dry acetonitrile $(2.4 \mathrm{~mL})$. All HPLC equipment was purchased from CHM GmbH, Fridolfing, Germany. The HPLC tubing used as flow reactor was made of PTFE with the measurements $1 / 16 \times \varnothing 0.25 \mathrm{~mm}$. The syringes containing the reagents were connected to the flow system with PEEK adapters (1/4- 28f - Luer, female) and 1/4 PEEK fittings. The T-mixers used were PEEK (1/4-28 with $1 / 16$ fittings and $\varnothing 0.5$ $\mathrm{mm}$ ) for low pressure applications. The third syringe was loaded on a separate syringe pump. The flow rate was adjusted to an overall flow rate of $7.5 \mu \mathrm{L} / \mathrm{min}$. The source of heating for the reaction was a PEG 600 oil bath. After passing the heating zone $\left(80^{\circ} \mathrm{C}\right)$ behind the second $\mathrm{T}$-junction $(4 \mathrm{~m})$ the reaction was terminated at the outlet with $5 \mathrm{~mol} \%$ aq thiosulfate solution. For work-up, the mixture was extracted with dichloromethane $(3 \times 10 \mathrm{~mL})$. The combined organic phases were separated, dried over magnesium sulfate and the solvent removed under reduced pressure.

\section{Phenylcarbamoyl azide (4a)}

The crude product was purified with a silica gel column using hexane $/ \mathrm{CH}_{2} \mathrm{Cl}_{2}$ 15:1 as eluent. Yield: $71 \mathrm{mg}(44 \%)$, colourless solid, mp: $106-107{ }^{\circ} \mathrm{C}$ (lit: $\left.107.1^{\circ} \mathrm{C}\right)$ [18].

${ }^{1} \mathrm{H}$ NMR $\left(500 \mathrm{MHz}, \mathrm{CDCl}_{3}\right): \delta 7.44\left(\mathrm{~d},{ }^{3} J_{\mathrm{HH}}=7.9 \mathrm{~Hz}, 1 \mathrm{H}\right.$, $\mathrm{H}-2), 7.33\left(\mathrm{t},{ }^{3} J_{\mathrm{HH}}=7.9 \mathrm{~Hz}, 2 \mathrm{H}, \mathrm{H}-1 / \mathrm{H}-3\right), 7.13$ (t, ${ }^{3} J_{\mathrm{HH}}=7.4$ $\mathrm{Hz}, 2 \mathrm{H}, \mathrm{H}-4 / \mathrm{H}-6), 6.97$ (s, 1H, NH) ppm; ${ }^{13} \mathrm{C}$ NMR (125 MHz, $\left.\mathrm{CDCl}_{3}\right): \delta 154.0(\mathrm{C}-8), 136.8$ (C-5), 129.2 (C-1/C-3), 124.6 (C-2), 119.2 (C-4/C-6) ppm; EI-MS m/z (\%): 162 ([M] $\left.]^{+}, 7\right), 119$ (100), 93 (64), 91 (56), 64 (32).

\section{4-Chlorophenylcarbamoyl azide (4b)}

The crude product was purified with a silica gel column using hexane $/ \mathrm{CH}_{2} \mathrm{Cl}_{2}$ 1:1 as eluent. Yield: $63 \mathrm{mg}(32 \%)$, colourless solid, mp: $103-105^{\circ} \mathrm{C}$.

${ }^{1} \mathrm{H}$ NMR $\left(500 \mathrm{MHz}, \mathrm{CDCl}_{3}\right): \delta 7.39\left(\mathrm{~d},{ }^{3} J_{\mathrm{HH}}=8.8 \mathrm{~Hz}, 2 \mathrm{H}\right.$, $\mathrm{H}-4 / \mathrm{H}-6), 7.29\left(\mathrm{~d},{ }^{3} J_{\mathrm{HH}}=8.8 \mathrm{~Hz}, 6.86(\mathrm{~s}, 1 \mathrm{H}, \mathrm{NH}) \mathrm{ppm} ;{ }^{13} \mathrm{C}\right.$ NMR (125 MHz, $\mathrm{CDCl}_{3}$ ): $\delta 154.0$ (C-9), 135.4 (C-5), 129.8 (C-2), 129.2 (C-1/C-3), 120.4 (C-4/C-6) ppm; EI-MS m/z (\%): $198\left([\mathrm{M}]^{+}, 2\right), 196\left([\mathrm{M}]^{+}, 4\right), 187$ (2), 185 (5), 155 (12), 153 (100), 127 (23), 125 (21); HRMS (EI): calc. for $\mathrm{C}_{7} \mathrm{H}_{5}{ }^{35} \mathrm{ClN}_{4} \mathrm{O}$ : 196.0146, found: 196.0145 .

\section{4-Bromophenylcarbamoyl azide (4c)}

The crude product was purified with a silica gel column using hexane $/ \mathrm{CH}_{2} \mathrm{Cl}_{2}$ 1:1 as eluent. Yield: $65 \mathrm{mg}(27 \%)$, colourless crystals, mp: $77-78{ }^{\circ} \mathrm{C}$.
${ }^{1} \mathrm{H}$ NMR $\left(500 \mathrm{MHz}, \mathrm{CDCl}_{3}\right): \delta 7.45\left(\mathrm{~d},{ }^{3} J_{\mathrm{HH}}=8.7 \mathrm{~Hz}, 2 \mathrm{H}\right.$, $\mathrm{H}-3 / \mathrm{H}-5), 7.34\left(\mathrm{~d},{ }^{3} J_{\mathrm{HH}}=8.7 \mathrm{~Hz}, 2 \mathrm{H}, \mathrm{H}-2 / \mathrm{H}-6\right) 6.84(\mathrm{~s}, 1 \mathrm{H}$, $\mathrm{N} H) \mathrm{ppm} ;{ }^{13} \mathrm{C}$ NMR (125 MHz, $\left.\mathrm{CDCl}_{3}\right): \delta 154.1(\mathrm{C}-7), 136.0$ (C-4), 132.2 (C-1), 120.9 (C-2/C-6), 117.4 (C-3/C-5) ppm; EI-MS $m / z$ (\%): 242 ([M] $\left.{ }^{+}, 100\right), 240$ ([M] $\left.]^{+}, 96\right), 231$ (25), 229 (27), 214 (10), 212 (19). HRMS (EI): calc. for $\mathrm{C}_{7} \mathrm{H}_{5} \mathrm{BrN}_{4} \mathrm{O}$ : 239.9641 , found: 239.9639 .

\section{2,4-Dimethoxyphenylcarbamoyl azide (4d)}

The crude product was purified with a silica gel column using hexane $/ \mathrm{CH}_{2} \mathrm{Cl}_{2}$ 1:4 as eluent. Yield: $47 \mathrm{mg}(21 \%)$, colourless solid, mp: $65-67^{\circ} \mathrm{C}$.

${ }^{1} \mathrm{H}$ NMR $\left(500 \mathrm{MHz}, \mathrm{CDCl}_{3}\right): \delta 8.02\left(\mathrm{~d},{ }^{3} \mathrm{~J}_{\mathrm{HH}}=8.6 \mathrm{~Hz}, 1 \mathrm{H}\right.$, $\mathrm{H}-4), 7.22$ (s, 1H, NH), 6.50-6.47 (m, 2H, H-1/H-3), 3.84 (s, $3 \mathrm{H}, \mathrm{H}-13$ or H-14), 3.80 (s, 3H, H-13 or H-14); ${ }^{13} \mathrm{C}$ NMR (125 $\left.\mathrm{MHz}, \mathrm{CDCl}_{3}\right)$ : $\delta 156.7$ (C-10), 153.4 (C-2), 149.3 (C-6), 119.9 (C-4), 109.9 (C-3), 103.9 (C-5), 98.7 (C-1), 55.7 (C-13 or C-14), 55.5 (C-13 or C-14) ppm; EI-MS $m / z$ (\%): 222 ([M] $]^{+}$, 10), 179 (100), 164 (31), 153 (18), 136 (52), 122 (10), 110 (11), 95 (12); HRMS (EI): calc. for $\mathrm{C}_{9} \mathrm{H}_{10} \mathrm{~N}_{4} \mathrm{O}_{3}: 222.0753$, found: 222.0755; IR (neat): 1531, 1711, 2144, $3415 \mathrm{~cm}^{-1}$.

\section{Azido(4-bromophenyl)methanone (5)[35]}

The crude product was purified with a silica gel column using hexane $/ \mathrm{CH}_{2} \mathrm{Cl}_{2}$ 1:1 as eluent. Yield: $54 \mathrm{mg}(24 \%)$, light yellow solid.

${ }^{1} \mathrm{H}$ NMR $\left(500 \mathrm{MHz}, \mathrm{CDCl}_{3}\right): \delta 7.87\left(\mathrm{~d},{ }^{3} J_{\mathrm{HH}}=8.8 \mathrm{~Hz}, 2 \mathrm{H}\right.$, $\mathrm{H}-4 / \mathrm{H}-6), 7.59$ (d, $\left.{ }^{3} J_{\mathrm{HH}}=8.8 \mathrm{~Hz}, 2 \mathrm{H}, \mathrm{H}-1 / \mathrm{H}-3\right) \mathrm{ppm} ;{ }^{13} \mathrm{C}$ NMR (125 MHz, $\left.\mathrm{CDCl}_{3}\right): \delta 171.7(\mathrm{C}-8), 132.0(\mathrm{C}-5), 130.8$ (C-1/C-3), 129.7 (C-2), 129.5 (C-4/C-6) ppm.

\section{N-Phenylpentanamide (6)}

Phenylcarbamoyl azide 4a (0.12 $\mathrm{mmol}, 20 \mathrm{mg})$ was dissolved in dry THF $(35 \mathrm{~mL})$ and cooled to $-78{ }^{\circ} \mathrm{C}$ under argon. Then $n$-BuLi ( $0.37 \mathrm{mmol}, 0.15 \mathrm{~mL}, 2.5 \mathrm{M}$ in hexane) was added carefully dropwise into the solution via a syringe. After the addition the cooling bath was removed and the flask was allowed to warm to r.t. The mixture was then diluted with AcOH/THF (20 $\mathrm{mL} / 20 \mathrm{~mL})$ and aq sodium carbonate $(20 \mathrm{~mL})$. Then ethylacetate $(60 \mathrm{~mL})$ was added, the organic layer separated and dried over magnesium sulfate. The crude product was purified with a silica gel column using hexane $/ \mathrm{CH}_{2} \mathrm{Cl}_{2}$ 15:1 as eluent. Yield: $14 \mathrm{mg}$ (quant.) colourless solid, mp: $60-61{ }^{\circ} \mathrm{C}$ (lit: $\left.60-61.5{ }^{\circ} \mathrm{C}\right)[36]$.

${ }^{1} \mathrm{H}$ NMR $\left(500 \mathrm{MHz}, \mathrm{CDCl}_{3}\right): \delta 7.51\left(\mathrm{~d},{ }^{3} J_{\mathrm{HH}}=7.9 \mathrm{~Hz}, 2 \mathrm{H}\right.$, $\mathrm{H}-4 / \mathrm{H}-6), 7.32\left(\mathrm{t},{ }^{3} J_{\mathrm{HH}}=7.9 \mathrm{~Hz}, 2 \mathrm{H}, \mathrm{H}-1 / \mathrm{H}-3\right), 7.13(\mathrm{~s}, 1 \mathrm{H}$, $\mathrm{NH}), 7.10\left(\mathrm{t},{ }^{3} J_{\mathrm{HH}}=7.4 \mathrm{~Hz}, 1 \mathrm{H}, \mathrm{H}-2\right), 2.36\left(\mathrm{t},{ }^{3} J_{\mathrm{HH}}=7.6 \mathrm{~Hz}\right.$, $2 \mathrm{H}, \mathrm{H}-10), 1.72\left(\mathrm{qn},{ }^{3} J_{\mathrm{HH}}=7.6 \mathrm{~Hz}, 2 \mathrm{H}, \mathrm{H}-11\right), 1.41\left(\right.$ sext, ${ }^{3} J_{\mathrm{HH}}$ 
$=7.5 \mathrm{~Hz}, 2 \mathrm{H}, \mathrm{H}-12), 0.95\left(\mathrm{t},{ }^{3} J_{\mathrm{HH}}=7.4 \mathrm{~Hz}, 3 \mathrm{H}, \mathrm{H}-13\right) \mathrm{ppm}$;

${ }^{13} \mathrm{C}$ NMR (125 MHz, $\left.\mathrm{CDCl}_{3}\right): \delta 171.3(\mathrm{C}-8), 137.9$ (C-5), 129.0 (C1/C-3), 124.2 (C-2), 119.7 (C-4/C-6), 37.6 (C-10), 27.7 (C-11), 22.4 (C-12), 13.8 (C-13) ppm.

\section{Acknowledgments}

We thank Cardiff University for support and the EPSRC National Mass Spectrometry Service Centre, Swansea, for mass spectrometric data. We thank Dr. Robert Richardson, Cardiff University, for discussions and for performing the calculations.

\section{References}

1. Wirth, T., Ed. Microreactors in Organic Synthesis and Catalysis; Wiley-VCH: Weinheim, 2008.

2. Yoshida, J. Flash Chemistry; Wiley: Chichester, 2008.

3. Banert, K.; Joo, Y.-H.; Rüffer, T.; Walfort, B.; Lang, H. Angew. Chem., Int. Ed. 2007, 46, 1168-1171. doi:10.1002/anie.200603960

4. Hassner, A.; Stern, M.; Gottlieb, H. E.; Frolow, F. J. Org. Chem. 1990, 55, 2304-2306. doi:10.1021/jo00295a014

5. Bräse, S.; Gil, C.; Knepper, K.; Zimmermann, V. Angew. Chem., Int. Ed. 2005, 44, 5188-5240. doi:10.1002/anie.200400657

6. Shellhamer, D. F.; Allen, J. L.; Allen, R. D.; Gleason, D. C.; Schlosser, C. O.; Powers, B. J.; Probst, J. W.; Rhodes, M. C.; Ryan, A. J.; Titterington, P. K.; Vaughan, G. G.; Heasley, V. L. J. Org. Chem. 2003, 68, 3932-3937. doi:10.1021/jo030030v

7. Curini, M.; Epifano, F.; Marcotullio, M. C.; Rosati, O. Tetrahedron Lett. 2002, 43, 1201-1203. doi:10.1016/S0040-4039(01)02358-9

8. Barluenga, J.; Alvarez-Perez, M.; Fananas, F. J.; Gonzalez, J. M. Adv. Synth. Catal. 2001, 343, 335-337. doi:10.1002/1615-4169(20010430)343:4<335::AID-ADSC335>3.0.CO; $2-\mathrm{V}$

9. Nair, V.; George, T. G.; Sheeba, V.; Augustine, A.; Balagopal, L.; Nair, L. G. Synlett 2000, 1597-1598. doi:10.1055/s-2000-7923

10. Rose, B.; Schollmeyer, D.; Meier, H. Liebigs Ann./Recl. 1997, 409-412.

11. Hassner, A.; Keogh, J. J. Org. Chem. 1986, 51, 2767-2770. doi:10.1021/jo00364a027

12. Hassner, A. Acc. Chem. Res. 1971, 4, 9-16. doi:10.1021/ar50037a002

13. Crotti, P.; Chini, M.; Uccellobarretta, G.; Macchia, F. J. Org. Chem. 1989, 54, 4525-4529. doi:10.1021/jo00280a016

14. Hassner, A.; Boerwinkle, F. P.; Levy, A. B. J. Am. Chem. Soc. 1970, 92, 4879-4883. doi:10.1021/ja00719a021

15. Baruah, M.; Bols, M. Synlett 2002, 1111-1112. doi:10.1055/s-2002-32593

16. Viuf, C.; Bols, M. Angew. Chem., Int. Ed. 2001, 40, 623-625. doi:10.1002/1521-3773(20010202)40:3<623::AID-ANIE623>3.0.CO;2G

17. Marinescu, L.; Thinggaard, J.; Thomsen, I. B.; Bols, M. J. Org. Chem. 2003, 68, 9453-9455. doi:10.1021/jo035163v

18. Pedersen, C. M.; Marinescu, L. G.; Bols, M. Org. Biomol. Chem. 2005, 3, 816-822. doi:10.1039/b500037h

19. Sahoo, H. R.; Kralj, J. G.; Jensen, K. F. Angew. Chem., Int. Ed. 2007, 46, 5704-5708. doi:10.1002/anie.200701434
20. Baumann, M.; Baxendale, I. R.; Ley, S. V.; Nikbin, N.; Smith, C. D.; Tierney, J. P. Org. Biomol. Chem. 2008, 6, 1577-1586. doi:10.1039/b801631n

21. Baumann, M.; Baxendale, I. R.; Ley, S. V.; Nikbin, N.; Smith, C. D. Org. Biomol. Chem. 2008, 6, 1587-1593. doi:10.1039/b801634h

22. Kopach, M. E.; Murray, M. M.; Braden, T. M.; Kobierski, M. E.; Williams, O. L. Org. Process Res. Dev. 2009, 13, 152-160. doi:10.1021/op800265e

23. Moss, R. A.; Terpinski, J.; Cox, D. P.; Denney, D. Z.; Kroghjespersen, K. J. Am. Chem. Soc. 1985, 107, 2743-2748. doi:10.1021/ja00295a029

24. Fowler, F. W.; Hassner, A.; Levy, L. A. J. Am. Chem. Soc. 1967, 89, 2077-2082. doi:10.1021/ja00985a019

25. Li, W.-S.; Thornton, J. E.; Guo, Z.; Swaminathan, S. PCT Int. Appl. 2002060904, 2006, p. 41.

26. Gaussian 98, Revision A.9; Gaussian, Inc.: Pittsburgh, PA, 1998.

27. Hay, P. J.; Wadt, W. R. J. Chem. Phys. 1985, 82, 270-283. doi:10.1063/1.448799 (Augmented LANL2DZ basis set).

28. Hay, P. J.; Wadt, W. R. J. Chem. Phys. 1985, 82, 284-298. doi:10.1063/1.448800

29. Hay, P. J.; Wadt, W. R. J. Chem. Phys. 1985, 82, 299-310. doi:10.1063/1.448975

30. Kirschning, A.; Monenschein, H.; Schmeck, C. Angew. Chem., Int. Ed. 1999, 38, 2594-2596. doi:10.1002/(SICI)1521-3773(19990903)38:17<2594::AID-ANIE2594>3 .0.CO;2-U

31. Zhdankin, V. V.; Krasutsky, A. P.; Kuehl, C. J.; Simonsen, A. J.; Woodward, J. K.; Mismash, B.; Bolz, J. T. J. Am. Chem. Soc. 1996, 118, 5192-5197. doi:10.1021/ja954119x

32. Marinescu, L. G.; Pedersen, C. M.; Bols, M. Tetrahedron 2005, 61, 123-127. doi:10.1016/j.tet.2004.10.040

33. Baxendale, I. R.; Hayward, J. J.; Lanners, S.; Ley, S. V.; Smith, C. D. In Microreactors in Organic Synthesis and Catalysis; Wirth, T., Ed.; Wiley-VCH: Weinheim, 2008; pp 84-122.

34. Lebel, H.; Leogane, O. Org. Lett. 2006, 8, 5717-5720. doi:10.1021/ol0622920

35. Mertens, A.; Arvanaghi, M.; Olah, G. A. Chem. Ber. 1983, 116, 3926-3930. doi:10.1002/cber.19831161215

36. Stanetty, P.; Koller, H.; Mihovilovic, M. J. Org. Chem. 1992, 57, 6833-6837. doi:10.1021/jo00051a030 


\section{License and Terms}

This is an Open Access article under the terms of the Creative Commons Attribution License

(http://creativecommons.org/licenses/by/2.0), which permits unrestricted use, distribution, and reproduction in any medium, provided the original work is properly cited.

The license is subject to the Beilstein Journal of Organic Chemistry terms and conditions:

(http://www.beilstein-journals.org/bjoc)

The definitive version of this article is the electronic one which can be found at:

doi:10.3762/bjoc.5.30 